\title{
Economics of the Financial Crisis: Any Lessons for the Pandemic Downturn and Beyond?
}

Hamid Elyassi

ABSTRACT The world economy entered the third decade of this century with uncertainties and challenges of COVID-19 pandemic before it had fully recovered from the lingering aftereffects of the financial crisis. The financial crisis ended a period of overall global economic growth and price stability during which globalization and its principles of trade, economic and political liberalization were widely held as the emerging international economic and political order. In domestic economy, most countries favored supply-side economics and monetary policy in a free-market setting. This paper appeals to economic logic and empirical evidence to critically study external and internal economic processes and policies particularly of major world economies to identify what caused the unanticipated onset of the banking crash and why the ensuing persistent downturn defied remedial measures. It concludes that major trading powers departed from their declared commitment to free trade and its basic rules with no effective institutional safeguards and deterrents. Internally, absence of efficient monitoring and supervision of workings of nominal and real sectors allowed anomalies to develop within the market economy unnoticed. As regards inefficacy of policies against several years of stagnation, the paper discusses asymmetric performance of monetary tools and problematic application of fiscal policy to suggest revisiting supply-side and Keynesian approaches against their past performance and forge an eclectic kit of analytical and policy tools alongside the necessary organizational reforms.

KEY WORDS: $\quad$ COVID-19 recession, financial crisis, monetary asymmetry, politicized Keynesianism.

JEL Classification: E6, E12, E32, E52, F6.

Namaya Consultants

\section{Introduction}

The third decade of this century began with a pandemic and the prospect of "the worst recession since the Great Depression and far worse than the Global Financial Crisis" (Gopinath, 2020) with foreseen annual economic growth of $-4.9 \%$ for the world, $-8.0 \%$ for advanced and $-3.0 \%$ for emerging markets and developing countries and "uncertain recovery" (IMF June 2020). And these before many economies had fully recovered from the lingering aftermaths of the banking crash of 2007-8. On the positive side, however, lessons of the causes and consequences of the financial crisis can provide a better insight into the

Correspondence concerning this article should be addressed to: Hamid Elyassi, 249 Westferry Road, London E14 3RS, UK. E-mail: hamid.elyassi@gmail.com working of modern economies and greater chance of effectively and rapidly dealing with the present challenge.

From the middle of the 1990s to the banking crash, the world economy enjoyed relative prosperity and stability with average rate of growth of around $3.3 \%$ at times hitting the 5.6\% mark. Advanced economies grew at an average annual rate of $2.0 \%$, in some years reaching over $4.0 \%$ and developing economies registered growth rates of between $5.8 \%$ and $8.5 \%$ which raised hopes of narrowing the gap between rich and poor nations (IMF Staff, 2000; World Bank, 2018b). In particular, emerging economies, many benefitting from direct foreign investment (FDI) principally by advanced countries, experienced spectacular growth and some, notably the People's Republic of China, gained prominence 
in international trade. Meanwhile under the banner of globalization as the roadmap to post-Cold War world order, economic liberalization in former socialist and many developing countries continued to spread democratic values and institutions and promote "integration of economies around the world, particularly through trade and financial flows" (IMF Staff, 2000). In this environment of optimism, some even expected continued prosperity with "no return to boom and bust" (Guardian, 2008).

This vision of the future was disrupted by the largely unforeseen onset of the financial crisis and the ensuing downturn which reduced the average growth rate of advanced economies to as low as $-3.7 \%$ and cut that of developing and emerging economies to mere $3.0 \%$, lower than at any time since mid-1990s (IMF, 2021). Moreover, the fact that more than a decade on, the world economy was yet to return to its pre-crisis stability despite remedial measures in various countries not only entailed immense economic and human costs, but also resulted in political backlashes. On the one hand, globalism was contrasted with patriotism and blamed for various economic ills (Rascoe, 2019) and on the other, it has been asserted that the financial crisis "vindicated the most virulent critics of globalization" (Huwart \& Verdier, 2013) and proved that globalization was just "another face of imperialism" (Veltmeyer, 2005). These stances have caused additional concern about tendencies to political introversion, economic protectionism and even trade wars (Chandy \& Brina, 2016; White, 2019) when international cooperation is needed to revive and protect the world economy.

The causes and consequences of the financial crisis have been extensively studied from different angles which provide a detailed ex-post overview of the course of events. Some actions have also been taken to prevent a repetition, including reform of the financial sector (Committee on the Global Financial System, 2018). However, the fact remains that the crisis and the resulting recession took most economists, economic analyst and policymakers unawares and despite policy measures put into effect in various countries, the world economy was still in a precarious state of health even before the outbreak of the pandemic. This raises questions about the state of macroeconomic theory and practice.
This paper examines some of these questions by appeal to empirical evidence and basic economic logic. It studies the interaction between internal and external functioning of major world economies before the crash to understand why the financial crisis could develop unnoticed. And more relevant to the present challenge, explores the principal theoretical and policy frameworks which worked satisfactorily in ensuring growth and stability in pre-crash years but did not perform as well in tackling the ensuing problems. It discusses and compares supply-side monetary and the Keynesian fiscal approaches and suggests revisiting their theoretical and policy attributes to forge an eclectic kit of analytical and policy tools within an appropriate methodological context with the necessary supportive policy and institutional infrastructures.

\section{Post-industrial order}

By the beginning of 1990s, economic and political changes in socialist-block counties were bringing down the ideological and political barriers to their assimilation into the world economy which provided economically advanced, "capital surplus" countries with fresh vistas for trade and foreign investment. Advanced economies themselves had been undergoing transition into the "postindustrial" stage of capitalist development characterized by high and rising standards of living and expectation of continually higher earnings (See Figure 1). This made the indigenous workforce too expensive to be employed in low productivity primary and basic secondary sectors and produce outputs at prices which would meet rising domestic consumption needs and compete in foreign market.

Instead, these economies had to allocate their human resources to advanced, high productivity tertiary and increasingly quaternary sectors, the latter encompassing "production" of technology through intensive R\&D and productization of the results in marketable "high-tech" consumption and capital goods and services and technical blueprints for domestic and export markets. As an example, in the United States, rising productivity was accompanied by fast growing inventions and innovations as represented by the rising number 


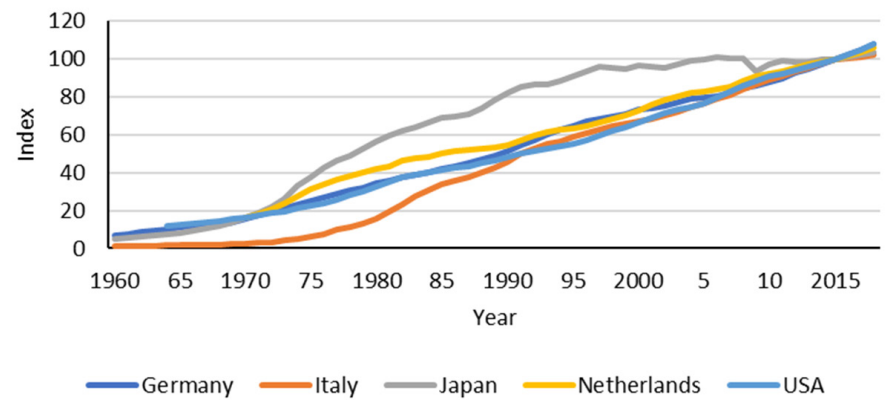

Figure 1. Historical wage indices in selected advanced countries (2015=100).

Source: FRED April 12, 2019; FRED Feb. 7, 2020; FRED Feb. 18, 2020; Pettinger, 2019.

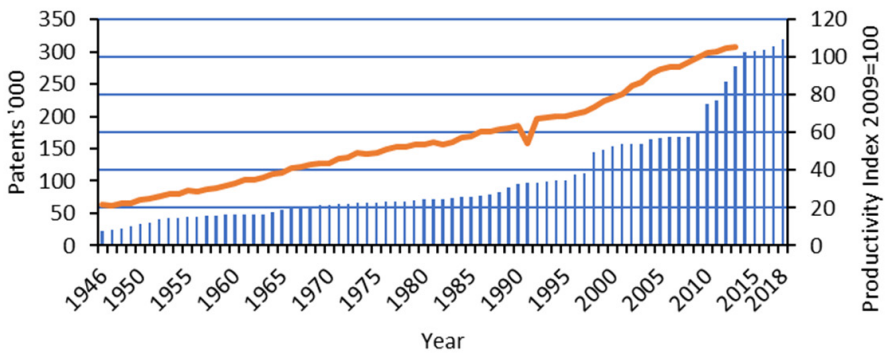

Patents Productivity

Figure 2. Labor productivity and patents granted (USA).

Source: U.S. Patent, 2020; Sprague, 2014. 
of inventions confirmed and patents granted (See Figure 2). Even though reallocation of labor was not always without political and social costs, as shown by the socio-political backlash of 1980s coal mines closure in the United Kingdom (Macintyre, 2014) and the advent of rust-city joblessness in the United States (Hufbauer \& Goodrich, 2003), continued production in low-productivity, often labor-intensive sectors was no longer viable in advanced market economies.

To meet domestic demand for the output of these sectors, production was delegated to economically less developed countries with relatively cheaper manpower and usually less stringent workplace regulations. The vehicle for this was extensive foreign direct investment (FDI), including in outsourcing (World Bank, 2017). For instance, between 1997 and 2007, American investors, no doubt attracted by considerable wage differentials (Table 1), transferred US\$633.3bn in FDI to China alone, of which nearly $66 \%$ went to the secondary manufacturing sector and $33 \%$ to local services (Liu, 2012) partly to develop the necessary infrastructures needed by modern manufacturing. This is not to mention investment by US affiliates. Extensive interaction between advanced and developing economy was instrumental in forming closer global economic interlinkages and a new pattern of international trade in which comparative advantages emanated from the partners' relative standards of living, intellectual creativity, and scientific and technological endowments.

Changes in center-periphery economic relationship has, of course, been a feature of successive stages of development of capitalism. For instance, nascent capitalism relied on economically backward areas as suppliers of raw materials and markets for its manufactured output, often accompanied by protective colonization. In later stages and alongside the advent of decolonization and establishment of independent sovereign states, the relationship changed into foreign direct investment in the context of import substitution industrialization (ISI). By the beginning of this century, post-industrial capitalist economies, particularly through the medium of transnational corporations, were already investing extensively in more labor-intensive, low technology production lines in less developed countries that offered suitable business environments (OECD, 2014).

In contrast to ISI investment, the motive for investment now was not to capture the host countries' markets but to surrender part of the investor's own domestic market to imported output of that investment. Today, transfer of production to less developed countries is extending to outsourcing of jobs and investment in services which amounted to over US\$92bn in 2019 alone (Statista 2020d). Thanks to the inflow of capital, suitable technology and entrepreneurship, some less developed countries, including some recently opened-up socialist economies, were rapidly drawn into an integrated global process of production and trade.

\section{Trading with the 'Socialist Work- shop of the World'}

Center-periphery economic relation in the post-industrial age is also different from earlier stages in that it has no need of military coercion or colonial compulsion. It espouses and is driven by the precept of mutual economic benefit in a liberal economic and free trade environment. As such, among fundamental prerequisite of healthy continuation of this relation is adherence to the rules of free trade which, among other things, require that for each partner, the trade inflow must be balanced by the outflow. Applied to the post-industrial center-periphery trade, the value of export of basic manufactured goods from the periphery to the center has to be balanced by the value of high-tech products imported from the advanced partner. Remarkably, though, for several years before the banking crash, the pattern of international trade seldom conformed to this paradigm of free trade. Instead, many advanced countries were running persistent and growing trade deficits with some emerging economies which in some instances, as with trade with the P.R. China, were assuming colossal proportions. For example, America's trade deficit with China grew consistently from a mere US $\$ 10.43$ bn in 1990 to US\$83.83bn in 2000 and US\$258.50bn in 2008 and has continued to rise since (US Census Bureau, 2020a).

Among the prerequisites of healthy free trade is unimpeded functioning of an automatic mechanism to correct trade imbalances. The mechanism is initially triggered in the currency exchange market to readjust the trading partners' relative currency exchange rates so as to make imports for the deficit country more expen- 
Table 1. Average Wages in USA and China* (Constant 2012 US\$)

\begin{tabular}{lcc}
\hline Year & China & USA \\
\hline 1990 & 611 & 12765 \\
1991 & 642 & 13724 \\
1992 & 681 & 15175 \\
1993 & 742 & 15438 \\
1994 & 762 & 16277 \\
1995 & 787 & 17609 \\
1996 & 789 & 19373 \\
1997 & 805 & 21699 \\
1998 & 846 & 24030 \\
1999 & 946 & 26783 \\
2000 & 1054 & 29829 \\
2001 & 1169 & 31267 \\
2002 & 1329 & 31898 \\
\hline
\end{tabular}

Source: Banister, 2004; Social Security 2020.

Note: ${ }^{\star}$ China: Average annual real wage urban manufacturing. US: Average net compensation.

Table 2. China's Foreign Reserves* and Household Expenditure (HE) as \% of GDP

\begin{tabular}{|c|c|c|c|c|}
\hline Year & Reserves \$bn & \% Change & HE \% GDP & \% Change \\
\hline 1995 & 66.3 & 78.9 & 45.8 & 3.8 \\
\hline 1996 & 91.4 & 37.9 & 46.9 & 2.4 \\
\hline 1997 & 126.3 & 38.1 & 45.9 & -2.1 \\
\hline 1998 & 145.2 & 14.9 & 45.6 & -0.6 \\
\hline 1999 & 155.8 & 5.2 & 46.3 & 1.5 \\
\hline 2000 & 162.0 & 6.0 & 46.9 & 1.2 \\
\hline 2001 & 191.0 & 17.7 & 45.8 & -2.3 \\
\hline 2002 & 251.2 & 31.1 & 45.3 & -1.1 \\
\hline 2003 & 360.8 & 43.6 & 43.2 & -4.6 \\
\hline 2004 & 494.6 & 37.1 & 41.2 & -4.6 \\
\hline 2005 & 724.6 & 46.5 & 40.2 & -2.4 \\
\hline 2006 & 949.5 & 31.0 & 38.3 & -4.7 \\
\hline 2007 & 1338.9 & 41.0 & 36.9 & -3.7 \\
\hline 2008 & 1804.5 & 34.8 & 36.1 & -2.1 \\
\hline
\end{tabular}

Source: FRED Jan 11, 2021; GlobalEconomy 2020

Note: ${ }^{\star}$ Excluding gold. 
sive and its exports cheaper, thus obliging its citizens to eliminate the deficit by working and selling more and buying and consuming less while the trade surplus nation's earlier abstinence is rewarded with cheaper imports and the need to export less. Although in real world the trade balancing process may not be quite as instantaneous or drastic because options such as foreign borrowing allow repayment to be spread over time, still trade deficit is an unsustainable external debt that has to be repaid. Nonetheless, that during the pre-crisis years the center-periphery trade imbalance was allowed to continue and grow shows that despite all-round emphasis on free trade doctrine and the establishment of international conventions and institutions to promote and safeguard it, the basic rules of free trade were disregarded and its corrective mechanisms frustrated by main parties to international trade.

The prime example was the People's Republic of China where the state, benefiting from extensive foreign investment, presided over a latter-day socialist 'workshop of the world' by putting an abundant, surplus labor force to manufacturing an expanding range and increasing volume of exportable products. Being in overall charge of the economy, the state was able to control wages and suppress consumption and enforce "involuntary savings" through a large and growing foreign reserves, in particular of hard currencies which by 2009 stood at nearly US\$2.0tn (Peltier, 2015; Setser \& Pandey, 2009). Rising foreign reserves were accompanied by declining share of household consumption in GDP (see Table 2) and worsening pattern of distribution which "rendered China among the most unequal countries in the world" (Jain-Chandra et.al., 2018).

Amassing foreign reserves meant that a considerable part of China's export earnings was not spent on imports and did not enter the exchange market to adjust parity rates and trigger the trade imbalance correcting mechanism. Quite the opposite. For example, the dollar/ yuan exchange rate was gradually raised from 1.60 in 1981 to 5.82 by 1993 within the state controlled floating system and then pushed up to 8.77 in early 1994 despite rising trade surplus with America. It was allowed to slide down only after the banking crash (Macrotrends, 2021). For European Union, while trade deficit rose continuously from $€ 51.3$ bn in 2001 to $€ 169.5$ bn in 2008 (Prevost, Choukroune, Creemers, \& Huchet, 2011), euro-yuan rate went up sharply from 7.4 9n in 2001 to
10.3 in 2004 and did not fall below 10.0 mark until 2009 (Statista, 2020c). Even that part of the surplus invested in bonds issued by advanced countries (ChinaPower, 2017) ultimately contributed to the trade gap by propping demand in the borrowing countries and supporting the value of their currencies against China's whether or not, as has been alleged, the country deliberately maintained an undervalued currency (Gradziuk, 2010).

\section{Paradoxes of Persistent Trade-deficit}

The fact that in advanced countries, trade deficit persisted for several years alongside satisfactory economic growth and price stability presents a theoretical paradox. In any economy, total purchasing power or aggregate effective demand consists of citizens' wages and profits earned as the value of labor and capital inputs in the production of total domestic output. To achieve market equilibrium, aggregate demand must equal aggregate supply of domestic output sold to citizens either directly or after exchange with imports. With trade deficit, aggregate supply exceeds aggregate demand so that a market glut should arise. This can be eliminated by fall in the price level, namely deflation, in domestic output, namely negative economic growth or both unless effective demand is raised by additional purchasing power injected from outside the system. The fact that during most pre-crash years, emerging and advanced trading partners enjoyed overall price stability, positive growth, and expanding trade despite persistent and increasing trade imbalance (Pehnelt, 2007; OECD, 2018) shows that effective demand in trade deficit nations was boosted and individuals and businesses acquired purchasing power in excess of their earnings as factors of production.

This additional purchasing power had to come either from monetary expansion at the initiative of monetary authorities, or expansionary fiscal measures of governments. The first option can be ruled out because independence of central banks confined them to maintaining price stability by responding to, rather than shaping the state of aggregate demand (King, 2017; Gould, 2008). Besides, there is no indication of deliberate expansionary monetary policy in these countries until the post-crisis downturn. For instance, in ten years preceding the financial crisis, Federal Funds Rate averaged $3.0 \%$ at times reaching $6.50 \%$ (Fedprimerate 2020) and the European Central Bank's Marginal 


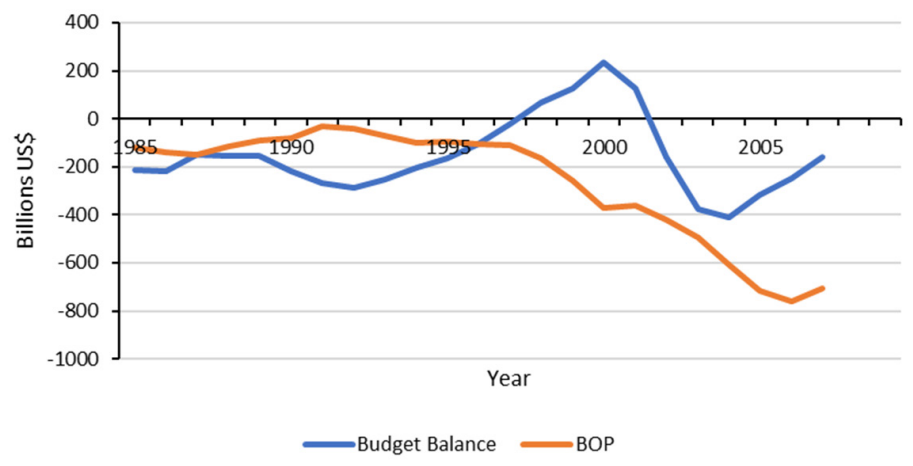

Figure 3. United States budget balance and balance of trade in goods and services (US\$ bn).

Source: Amadeo, 2020; US Census, 2020c

Lending Facility was never below $3.0 \%$ and at times stood as high as $5.75 \%$ (ECB, 2021). In contrast, from the beginning of the 2000s to the banking crash, annual budget deficits in European Union countries averaged $2.16 \%$ of GDP with few instances of balanced or surplus budget (OECD, 2020). In America, except for four years, the federal budget was in deficits of as high as $\$ 455$ bn from 1990 to 2008 (Murse, 2020) alongside growing trade deficit (see Figure 3 and Appendix 1).

The deficit was distributed to households and businesses as direct and indirect state benefits and boosted their purchasing power. This filled the supply-demand gap resulting from excessive imports and helped maintain market equilibrium and price stability. Meanwhile, the monetary sector was providing sufficient liquidity to lubricate the system. The whole process, of course, required the existence of trade partners willing to exchange their real outputs with hard currencies to add to foreign reserves, an inclination reminiscent of the Bullionists of bygone ages except that instead of items of intrinsic value, now fiat moneys of hard-currency nations were accumulated.

Using budget deficit can solve the paradox of deficit countries' internal market equilibrium, but it presents another paradox. A budget deficit is financed either by the central bank's mandatory lending to the government, which central bank independence precluded in this period, or by government borrowing mainly through sale of interest-bearing bonds on domestic and foreign markets. In the period under discussion, Western governments financed their budget deficits principally by issuing and successfully selling large volumes of bonds. Some of the issues were acquired by investors from less developed countries, including trade surplus ones, but the bulk went to citizens of advanced countries themselves (Abbas, et al., 2014; Morrison \& Labonte, 2013). It is paradoxical that at a time when these governments had to borrow to prop up deficient aggregate demand, their nations had spare purchasing power to invest in bonds or in effect lend to themselves. In other words, how these nations collectively were able to spend more than they earned and at the same time, save enough to lend? The answer is found in a phenomenon that made people richer than they actually were, allowed excessive borrowing and eventually spelled the end the period of prosperity. 


\section{5. "Virtual Wealth"}

The period of worldwide prosperity did not end because of changes in the pattern of international trade or budgetary behavior of trade deficit governments. It was triggered by contagious banking failure in several advanced countries which, with the benefit of hindsight, is blamed on a dysfunctional transnational financial industry admitting a growing number of new entrants and allowing extensive diversification into different areas of operation by established operators. The result was an intensively competitive, highly lucrative and overconfident business environment in which some operatives stretched their resources so thinly as to turn irresponsible lending into normal banking practice. In this environment, governments, especially those with hard currency status, were able to borrow even beyond their creditworthiness without this negatively impacting the market yield of their bonds. The most publicized example was Greece which, by sharing a hard currency with some major world economic powers, managed to overspend and accumulate debts of over $133 \%$ of its nominal GDP (OEIC, 2019) without fall in yields until after the banking crash and amidst fear of possible sovereign default (De Santis, 2012).

Governments were not alone in benefitting from the lending frenzy. As Figure 4 shows, private borrowers were also treated favorably by credit institutions. For business borrowers, expected continuation of economic growth and booming demand probably seemed sufficient surety of their ability to service their debt. More remarkable was readiness of financial institutions to lend extensively to individuals and households whose loan applications normally succeed only if backed by some item of marketable wealth as collateral. The collateral was supplied by ever more expensive real estate.

For a decade or so before the banking crash, almost all major economies were witnessing hyperactive real estate markets (The Economist, 2005) and rapidly rising property prices in excess of the rates of economic growth and inflation - inflation itself partly fueled by rising property prices (Table 3 ). As a rule, rapid rise in property prices is associated with significant changes in demographic conditions or spending culture of a country, backed by growing incomes to enable households and businesses to afford the purchase. These conditions are more typical of a developing country enjoying rapid economic growth than economically advanced countries which are unlikely to experience economic and social shifts of such magnitude and speed as to send property prices racing far ahead of the rates of inflation and economic growth in the space of a few years. But even if in the relatively stable socioeconomic settings of advanced, Western countries, the desire to own new or better quality property abruptly leaps to the head of citizens' wish list, without sufficient funds to finance the purchase, potential demand cannot impact the price, especially because for most buyers, the fund needed to purchase a piece of real estate can seldom come from short-term adjustments in the household budget but requires access to a large lump-sum, even for a down-payment.

Rising property prices in this period did encourage some additional investment in the construction sector, as for example, indicated by growth of privately-owned housing output in the United States in 2004- 2006 (US Census Bureau, 2020b). But continued property price rise was a sign that buyers had access to the necessary funding to keep demand well ahead of supply. In fact, price explosion in a buoyant property market was turning real estate into an increasingly valuable marketable asset, making owners "wealthier" and more creditworthy as potential borrowers and spenders. Meanwhile, the lenders' lax credit policy enabled buyers with no or little initial funds to enter the real estate market through easy mortgages secured against property yet to be owned. In other words, borrowers' creditworthiness was not based on true wealth representing accumulated personal or inherited savings made out of real incomes but on revaluation of a relatively given stock of real estate which the financial sector treated as true wealth and accepted as collateral for loans. Extensive lending further boosted demand, including for housing (Bianco, 2008), inflated real estate prices and made for "wealthier" borrowers and bolder lenders. On the back of the augmentation of what amounted to a phantom or 'virtual wealth', a hyperactive financial sector felt no qualms about generous lending to individuals, businesses, including other financial institutions, and governments at home and abroad (OECD, 2019). Even if we accept that, at least in the United States, there was no relaxation of collateral constraints by lending institutions (Justiniano, 2015), still granting loans against overvalued property owned and yet to be owned had 


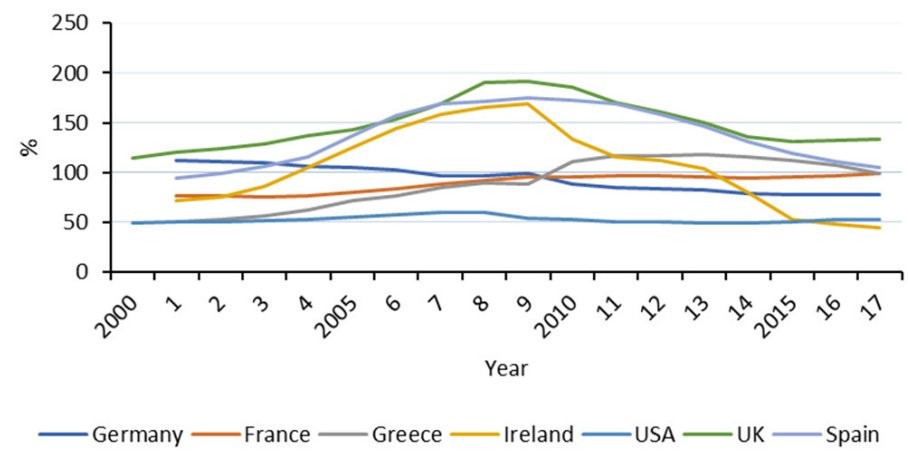

Figure 4. Domestic bank credit to private sector as \% GDP - Selected Countries.

Source: World Bank, 2019.

Table 3. Average Annual Rates of Change in Property Prices, Inflation and GDP*; Selected Countries - 1997-2007 (\%)

\begin{tabular}{lccc}
\hline & Property Prices & CPI & GDP \\
\hline France & 9.65 & 1.8 & 2.41 \\
Germany & 10.65 & 1.3 & 1.69 \\
Greece & 10.44 & 3.2 & 3.97 \\
Ireland & 15.44 & 3.3 & 6.49 \\
Spain & 13.82 & 3.1 & 3.88 \\
UK & 13.01 & 1.6 & 3.05 \\
USA & 9.28 & 2.8 & 3.22 \\
\hline
\end{tabular}

Source: FRED, May 24, 2018; FRED Aug 10, 2018; Allen, Goldstein, Jagtiani \& Lang, 2016; World Bank various years Note: ${ }^{\star}$ Market Prices

the same effect as sub-prime lending in creating unwarranted household debt and triggering the subsequent wave of foreclosures (André, 2016). Moreover, these loans, secured though they were against inflated property values, or the "virtual wealth", formed part of lending institutions' tradable assets and further expanded their operational capability.

To sum up, while in normal economic circumstances, persistent trade and budget deficits can each under- mine economic growth and price stability, for several years before the banking crash, they went hand-inhand in major economies with satisfactory growth and stable prices. The reason was a combination of the unusual attitude of some major trading countries to the basic philosophy and functional mechanism of free trade alongside the role of financial institutions in a hyperactive property market. Only when doubts about the realness of the 'virtual wealth' and the credit- 
worthiness of some borrowers crept in did the system collapse and, thanks to the economic and financial interlinkages in the global village, the shock rapidly reverberated the world over and resulted in worldwide economic sluggishness, downturns or outright recessions.

\section{Policy Response}

Even though tacit international consensus to avoid unilateral anti-recession measures alongside in-built counterrecessionary mechanisms in most countries prevented the post-crash downturn from turning into another Great Depression (Napolitano, 2011), much of the world economy ended the second decade of the century still grappling with retarded growth and intermittent stagnation (Mann, 2017). During these years, the average rate of growth of world economy struggled around 3.3\% while advanced economies grew at an average rate of 1.4 after hitting a low of $-3.3 \%$ and emerging economies managed only an average rate of below 5\% (IMF 2021). Meanwhile, in line with the dominant economic thinking of recent decades, the main remedial measures put in place in most countries centered on monetary devices of cutting interest rates to encourage borrowing and easing money supply to make more funds available to potential borrowers. The intention was to boost effective demand by restoring consumer and business confidence, the weakness of which was blamed for preventing a sustained upturn. That the remedies did not prove quite effective and that the prevalent economic approach had failed to identify the cause and predict the onset of the recession in the first place suggest the need to revisit the current economic thinking and explore the alternatives which, given the present state of economic knowledge and barring a radical revolution in the global economic order, primarily point to the Keynesian school of fiscal management.

Following the Great Depression and especially after World War II, the Keynesian school provided the principal macroeconomic policy framework in most Western countries until its credibility was dented largely by weakness in explaining and stemming the menacing threat of stagflation of the 1960s and 1970s. Relegation of Keynesianism was further precipitated by changes in the official economic ideology in the United States and the United Kingdom from early 1980s when governments committed themselves to reducing state intervention in the economy and replacing fiscal regulation with less intrusive monetary instruments to deal with occasional deviations from the presumed inherent equilibrium of the marketcommanded economy (Niskanen, 1988; Gamble, 1988; Johnson, 1991; Pierson, 1994). The idea was that instead of acting as the supreme regulator of the economy, the state should withdraw to the margin and allow free - or at any rate freer - market mechanism to guide the economy on its natural path with independent monetary authorities entrusted with the more passive task of preserving the internal value of the national currency through responding to, rather than actively generating changes in the real sector.

These changes in political and economic thinking seemed to bear tangible result when, after several years of theoretical perplexity and political despondency, Western economies emerged from the worst of the stagflation crisis to enjoy a fair degree of stability and relative prosperity. In the circumstances, it was hard to challenge the validity of the now-mainstream macroeconomics which claimed credibility on empirical grounds and authority through political conviction. That is until the financial crisis pointed to the shortcomings of the dominant school's forecasting and corrective instruments and cast doubts on its presumed infallibility, much as stagflation had challenged Keynesian supremacy.

\section{Monetary Adjustment}

Can monetary policy, as the comparatively proactive arm of supply-side economics, be credited with ending the historical stagflation and maintaining price stability over the subsequent several years? There seems to be no conclusive answer. The period of stagflations was the time of rapid, sometimes tumultuous economic and political happenings at the global level. Apart from economic ramifications of political issues such as escalating arms race and continuation of the Vietnam War (Riddell, 1989), from early 1970s, crude oil prices began to rise rapidly to peak in early 1980s before going on a long-drawn downslide well into late 1990s (Kilian, 2009; Elyassi, 2018). It is not implausible that just as rising energy prices had introduced elements of cost-push inflation into Western economies, the downward glide helped ease that pressure (Figure 5).

The decade 1980s also witnessed immense progress in information technology which ushered in a phase in the history of capitalism not incomparable to the railways boom and the age of automotive and electrical innova- 


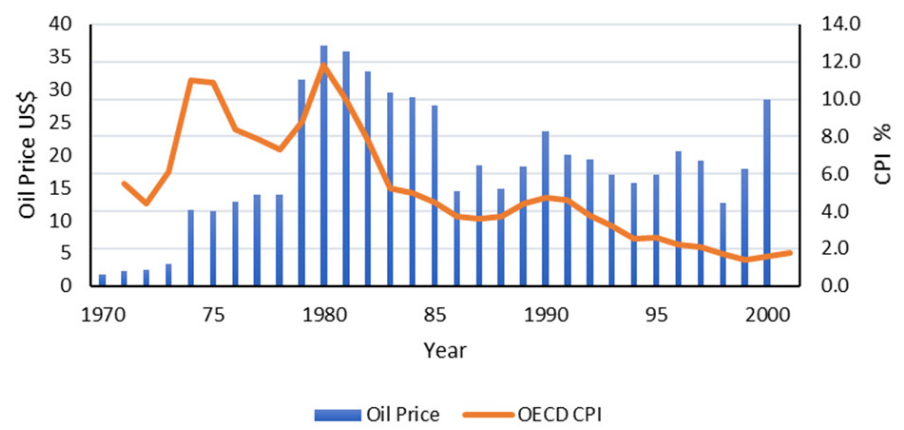

Figure 5. Oil prices (US\$) and average inflation rate in OECD countries (1970-2000).

Source: FRED, Apr 2017; Quandl, 2019.

tions in creating new opportunities for investment, employment and growth. This was followed by historically significant political and economic changes in Eastern bloc countries. The end of the Cold War not only released immense resources from the military sector, for instance reducing OECD military spending from 4.07\% of GDP in 1982 to $3.01 \%$ in 1990 and $2.09 \%$ in 2000 (and even greater reductions in former socialist states) (World Bank, 2018a), it opened fresh vistas for international trade and investment.

The impact of this propitious combination of economic, technological and political factors, the opportunities it generated and the optimism it inspired cannot be ignored in ending stagflation and creating a new global economic environment of growth potentials. Nonetheless, realization of these potentials without jeopardizing price stability required a prudent and effective monetary framework, prompting the conclusion that while supplyside economics and its associated monetary policy cannot be conclusively credited with ending stagflation and starting a period of economic improvement in the West and elsewhere, appropriate monetary instruments must have safeguarded price stability. At the same time, the fact that monetary instruments do not seem to have performed well in reviving global economy after the financial crisis, may intimate that the monetary approach offers effective solutions in some, but not all economic conditions.

To achieve the desired state of the economy, monetary policy relies on adjustments in money supply and interest rate to influence consumers' and investors' demand for money to spend. When the economy is overheated and at the risk of inflation, raising the interest rate is expected to discourage people from increased spending by placing a premium on holding money and raising the cost of borrowing relative to the expected incremental increases in utility and profit from additional consumption and investment. Similarly, tighter money supply aims at making it more difficult for consumers and investors to access funding. Conversely, in a slowdown, cheaper and more easily accessible loans are meant to encourage dissaving and borrowing and boost demand. Why this straightforward mechanism should not work always and in all conditions?

The efficacy of any macroeconomic policy device in correcting an economic disturbance depends on two conditions: First, the internal and external consistency of the underlying theory, that is its logical coherence and compatibility of its conclusions with empirical data; secondly, 
the policymaker's competence in using the theory to correctly diagnose the nature of the disturbance, choose and apply the appropriate policy measures at the right time and ideally, anticipate and take care of possible sideeffects. Although policymakers' inadequacy can never be ruled out as the reason for the failure of a corrective measure, it is unlikely that monetary authorities throughout the world were inept in employing monetary tools to deal with their post-crash economic problems. It seems more plausible that monetary policy, as a kit of corrective macroeconomic tools, has problems of theory rather than application.

For a change in the rate of interest, as the going price of money, to impact the level of economic activity, it must change people's demand for money in the right direction and magnitude. Yet, the quantity-price demand function for all goods, including money, is not unique and, as indicated by the ceteris paribus proviso, demand is a function of a multitude of variables of which price is usually taken to be the prime, but not always the sole mover. If variables other than price change and influence demand, the quantity-price relation may break down. Among the ceteris paribus variables that greatly impact demand for certain products is demand for other, closely related goods, particularly when demand for the first product is secondary to or is derived from the primary demand for another. In the case of a strongly correlated derived demand function, demand for the primary product and factors affecting it may have greater impact on derived demand for the secondary product than its own price.

Money is a prima facie example of a secondary good because in itself, it imparts no utility to the consumer or profit to the investor. Money is demanded to satisfy primary demand for other products to consume or employ in production. If that primary demand refuses to change for any reason other than the cost of funding, then changing the price of money is unlikely to greatly influence the intended borrowers' decision to borrow more or less money to spend. In an economic downturn, if consumers and investors are reluctant to spend, then changing the rate of interest may have little or no bearing on the state of aggregate demand. Conversely, strong potential demand for goods and services in an upturn may increase demand for money irrespective of changes, at least moderate changes, in the interest rate. Likewise, changes in money supply may not encourage or discourage borrowing unless accessibility of funds is the main factor affect- ing general demand for goods and services.

After the banking crash, monetary authorities in many countries repeatedly slashed the interest rate and applied quantitative easing against a stubborn downturn, clearly without the desired outcome (Bouis et al., 2013). In the United Kingdom, for example, the Bank of England (central bank) lowered the interest rate on several occasions with no statistical indication of effect on relevant economic variables (Appendix 2).

\section{Monetary Asymmetry}

If monetary instruments have performed well at times but not always, this may suggest that their impact is asymmetrical depending on the nature of the problem they address and conditions in which they are employed. For instance, when strong confidence in the current state of the economy and optimism about its future create robust but unfulfilled potential demand for consumer and investment goods, cheaper and more accessible money can translate the potential demand into effective market demand. Now, if aggregate demand is below the desired level, monetary expansion should deliver. In the same environment, if the economy faces inflationary tendencies because of the pressure of demand, making funds sufficiently scarce and setting the interest rate sufficiently above the anticipated marginal profit from additional investment and value of marginal utility from additional consumption can dissuade some potential borrowers from their intended spending. It is, therefore, reasonable to suggest that in times of relative economic stability and prosperity when positive outlook of consumers and investors ensures that potential aggregate demand is close to the desired level, readjusting the cost and availability of funds may fine-tune the economy and smooth over occasional disturbances. Besides, in societies with economically well-informed citizens, the public is likely to respond to corrective monetary measures in the expected manner and reinforce the intended outcome. But what about instances of prolonged periods of high inflation or deep recession when consumers and businesses, uncertain about the future, prefer the safety of avoiding making decisions to the risk of making the wrong ones?

Whether monetary policy can remedy a steeper and more persistent inflation depends on the root cause. For example, neither monetary nor fiscal measures would be effective against inflations caused by rising cost of imported materials. This has to be addressed by structural 
readjustment to the state of technology and/or pattern of trade. Or when for any reason, there is a surge in potential aggregate demand but no prospects of a corresponding increase in supply, preventing inflation requires either suppressing excess potential demand or preventing it from entering the market as purchasing power. The first option requires discovering and dealing with the root cause of consumers' and investors' increased propensity to spend which is often related to a host of economic and non-economic factors, some easy for policymakers to identify and treat, others not. It is, therefore, impractical to formulate a generalized economic policy approach to deal with factors behind excessive potential demand. But the relationship between potential and effective aggregate demands is a mechanical one and, at least from a theoretical perspective, it is possible to contain excessive potential demand by employing suitable monetary tools to make borrowing too costly and/or less accessible to consumers and investors. Conceptually, this can be achieved by a policy mix of inhibitive interest rates and control over all forms of money supply.

The same line of reasoning, however, does not apply to recessions or persistent slumps when "primary demand" for goods and services is less than is needed to bring about the desired level of economic activity because consumers and investors are reluctant to spend even if they have the necessary funds or are able to borrow cheaply and easily. This is the classic case of weak consumer and business confidence when demand deficiency is no longer the result of difficulty or cost of borrowing but of public unwillingness to spend. In such conditions, cheaper and more accessible loans cannot be relied on to entice consumers and investors to borrow or part with their savings and spend more. In the worst-case scenario of deep economic gloom and "negative inflation", even the conjectural and rather desperate act of dropping banknotes from a helicopter may fail to invigorate demand but simply give the recipients the opportunity to save the windfall against worse times ahead or benefit from lower prices to come.

To sum up, monetary policy may do well in fine-tuning and maintaining stability in a healthy economy by boosting mildly sluggish or dampening slightly excessive potential demand. At least conceptually, it can also work in more severe cases of inflation by starving potential demand of money needed to turn it into effective market demand. But in a recession caused by public reluctance to increase consumption and investment, cutting the price and increasing the availability of loanable funds cannot be relied upon to work unless the underlying causes, or the ceteris paribus variables undermining the "secondary" demand for money are addressed. It can, therefore, be asserted that at least from a theoretical point of view, monetary tools perform asymmetrically in dealing with different states of economic disequilibrium. This is of relevance in assessing the effectiveness of monetary instruments in ending the lingering economic sluggishness after the financial crisis which can hardly be described as a mild, temporary slowdown in time of prosperity and optimism. It came after an unexpected financial shock that deprived millions of households of their valuable assets of real estate, bankrupted thousands of businesses including in the financial sector, entailed loss of income and slashed the purchasing power of the victims of unemployment and foreclosure and caused anxiety about the future among those not similarly affected. It is also important in devising effective measure to encounter the expected economic consequences of the COVID-19 pandemic.

\section{9. "Politicized" Keynesianism}

If monetary tools were unable to restore sustained growth to the world economy after the banking crash, might some alternative fiscal measures forged within the framework of the Keynesian school have done better in ending a persistent stagnation and thereafter, ensured economic stability?

Notwithstanding the diverse interpretations of Keynes' ideas, his basic theoretical model is a mathematical identity between the main elements of the national accounts. His contribution was to discover that in times of depression, it is necessary and useful to disturb the identity by tampering with its elements and force it to hold at a higher, "full-employment" level. As an identity, the model is tautological, therefore internally consistent and because its elements are real world data, it does not run the risk of external inconsistency which is often associated with the degree of abstraction of assumptions of a theory from reality. Therefore, failure of the model to solve a relevant problem, or any undesirable side-effect resulting from employing it, is likely to be caused by the manner of its application. It is argued here that in addition to the question of correct understanding of the nature and dimensions of the economic problem to be addressed and the right choice and quantitative accuracy of the remedial measures to be applied, application of the Keynes- 
ian model carries the additional risk of admitting noneconomic factors to creep in, and even override primary economic objectives.

As far as Keynes' own writings indicate, he intended his model to take care of demand deficiency as the cause of depression, with the well-known pronouncement that with the restoration of economic activity to the desired level "the classical theory comes into its own again from this point onwards" (Keynes, 1936, p. 378). Yet, Keynesian policy instruments provided the democratic state with a convenient and politically legitimate apparatus to manipulate the economy for political ends, for instance to boost demand, raise employment and create a sense of wellbeing when the good will of the electorate was needed before a general election, and defer the treatment of the potential negative side-effects, such as balance of payments deficit, to politically more expedient times. Figure 6 shows the example of the United Kingdom where, until the passage of the Fixed Term Parliament Act of 2011, prime ministers enjoyed the Royal Prerogative of dissolving the parliament at any time during the five year legislative term and where Keynesianism provided the main policy framework for both center-right Conservative and center-left Labor governments after World War II until early 1980s.

Keynesian tools also enabled the state to disguise fundamental economic disorders, such as structural causes of unemployment, and defer their treatment to politically less unfavorable opportunities, thus compounding the risk of embedding them as chronic maladies. In short, Keynesian tools allowed the elements of the "alien" world of politics to infiltrate and at times take over the economic decision-making process and perhaps subvert the outcome of an otherwise logically plausible economic theory. As an economist, Keynes could anticipate the economic outcomes of his model as he intended it to be applied, but economic methodology of his time - and indeed of ours - did not equip him to foresee and deal with the consequences of the political use of the model or incorporate them into his theory. For that, a holistic social model constructed in an interdisciplinary methodological framework was and is still needed.

Still, the Keynesian fiscal approach did not lose its predominance in most Western countries because of defeat in some methodological polemics but primarily because of its inability to explain and offer a solution for the problems of stagflation, namely, the concurrence of inflation and stagnation as mutually exclusive states of the economy in Keynesian thinking. There is perhaps still room to further investigate to what extent stagflation was the result of decades-long application of Keynesian model, perhaps with political motives, in much of the capitalist world, and to what extent was caused by global factors from rapidly rising oil prices to economic imperatives of the Cold War, and whether the solution came from switching to the new, supply-side school of economics or from positive changes in the global economic and political conditions. What cannot be disputed is that the monetary successor to Keynesian economics has not performed sufficiently well either, this time in predicting the financial crisis and dealing with the ensuing downturn, a condition for the treatment of which the Keynesian model was originally devised. It can perhaps be asserted that on balance, monetary tools perform better in management of short-term fluctuations than ending persistent downturns, while Keynesian fiscal approach may provide more effective solutions for recessions and persistent cases of economic disequilibrium.

In this, differences in the point and speed of impact are important. Changes in monetary variables must affect the economy largely through terms and conditions offered to clients by financial intermediaries, themselves private businesses prone to the general economic outlook, including the state of business confidence. Keynesian fiscal tools, on the other hand, are handled by the state and include a range of tax and expenditure options which can target intended areas of economic concern with approximately calculable impacts (see Table 4). Fiscal tools can also be made target-specific for maximum effect. For instance, state benefit and tax cut favoring social groups with higher propensity to spend boost demand more rapidly while government purchases or sales tax cuts prioritizing domestically produced goods have greater effect on private investment and employment. There is, of course, the risk that political considerations may outweigh the intended economic objectives. To mitigate the risk, administration of Keynesian macroeconomic policies should ideally be supervised, and the outcome monitored by some apolitical, or politically independent and non-partisan entity.

In view of the checkered past performances of the main schools of macroeconomic thought and the challenges they face in theory and practice, the question is whether we should concede that the world has come 


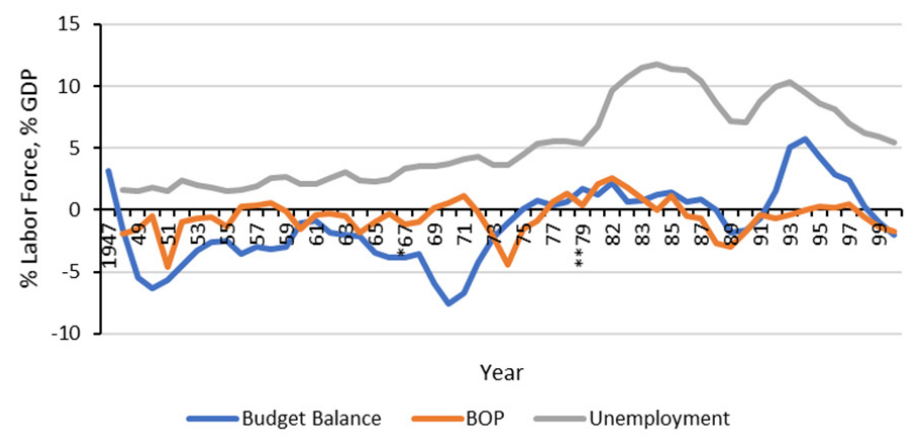

Figure 6. UK General Elections: Budget balance (\% GDP), unemployment (\%), balance of payments (\% GDP) Source: Office for National Statistics, 2019; Chantrill, 2019; FRED March 12, 2018

Table 4. Estimated Range of Multiplier Effects of Fiscal Options, USA (\%)

\begin{tabular}{lcc} 
Year & China & USA \\
\hline Type of Activity & Low Estimates & High Estimates \\
Purchase of Goods and Services by the Federal Government & 0.5 & 2.5 \\
Transfer Payments to State and Local Governments for Infrastructures & 0.4 & 2.2 \\
Other Transfer Payments to State and Local Governments & 0.4 & 2.1 \\
Transfer Payments to Individuals & 0.4 \\
One-time Payments to Retirees & & 1.0 \\
Two-Year Tax Cuts for Lower- and Middle-Income People & 0.2 & 1.5 \\
\hline
\end{tabular}

Source: Whalen \& Reichling, 2015. 
full circle back to the heydays of political economy when booms and busts were taken as natural part and parcel of capitalism to be endured helplessly until they cured themselves in the proverbial "long-term"? If not, how a choice is to be made between the two competing macroeconomic schools that have succeeded and failed to perform satisfactorily at different times?

\section{Conclusion and Recommendations}

The banking crash ended a period of relative worldwide economic prosperity and price stability. This was also a period of closer linkage of national economies rationalized by the notion of globalization and its principles of trade, economic and political liberalization. This paper argued that this period ended in an economic debacle not because of adherence to those principles and ideals, but as a result of their being neglected especially by major economic and trading powers.

In international trade, there was persistent and growing trade imbalance notably between advanced and some emerging economies without the in-built alarm signals of free trade regimen being triggered and its corrective processes activated. This paper argued that the reason was on the one hand, the behavior of some major exporters who gave priority to building currency reserves as the objective of international trade and on the other, the willingness of major importing states to afford their people greater immediate welfare by creating mounting external debts. Imbalanced trading continued despite allround emphasis on free trade doctrine and international conventions and institution set up to advance and protect its rules because in practice, these institutions were called upon to intervene only in inter-state disputes over "unfair" trading but remained largely inert in face of violation of free trade rules by mutual consent. If free trade is what the world is committed to, it is necessary to prevent a repetition of the same economic failure by addressing imbalanced trading regardless of the partners' attitudes. This needs independent entities empowered to initiate proactive intervention in defense of free trade principles and rules.

At the domestic level, this period saw almost systematic budget deficit in most advanced economies. Remarkably, the resulting demand expansion failed to raise the usual warning alarm of price inflation (Ihrig \& Marquez, 2003) thanks partly to excess imports filling aggregate demand-supply gap. In the monetary aspect, with mon- etary authorities confined to the passive task of maintaining general price stability regardless of developments in the rest of the economy, an intensively buoyant property market enabled the financial sector to expand credit on the back of a "virtual wealth" created by rising property prices. Despite the experience of Japan's property bubble of 1980s and the resulting several years of economic stagnation (Shiratsuka, 2015), there was little or no effective supervision or attempted intervention by governments or monetary authorities presumably because of "pre-crisis consensus on monetary policy not to act on asset price bubbles" (Stark, 2011). With the benefit of hindsight, it now seems that in dividing fiscal and monetary responsibilities between government and monetary authorities, the need for an entity with the holistic task of monitoring the overall functioning of the economy and empowered to raise the alarm in case of flaws and incongruities in real or nominal sectors had been overlooked.

Setting up institutions and procedures to ensure external and internal health and efficiency of the market economy is necessary to discern and prevent defects from forming in the system and leading to failures such as the banking crash. Of more immediate concern, however, are lessons learned from policy responses to the post-crash global downturn. The COVID-20 pandemic has forced many countries into various degrees of lockdown and suspension of economic activities, making a severe global downturn almost unavoidable. Meanwhile many governments have committed large unforeseen expenditures to compensate for loss of private incomes, thus creating large debts with every prospect of reduced revenues for some time to come. The result will entail serious dilemmas for fiscal and monetary policy. There will be the choice between austerity measures of raising taxes and reducing expenditures to curb national debt and continued fiscal expansion to encourage growth and expand the future revenue base. There will also be the choice between opting for low interest to keep down the cost of public and private borrowing and raising the rate for fear of price instability. The experience of remedial actions against the post-banking crash downturn can help in making more effectual choices.

In most countries, policy response to post-banking crash downturn consisted of expansionary monetary policies which, on the whole, did not perform effectively or speedily enough. This paper looked at the mechanics of monetary policy and suggested that while it had done well 
in ensuring stability in pre-crisis years of prosperity, its inability to deal with protracted stagnation may indicate that monetary tools tend to function asymmetrically. It was argued that the alternative Keynesian fiscal approach, which some have proposed for the post-crash downturn (Furman, 2008; Davidson, 2009) cannot be reinstated without bearing in mind its past performance and the risk of being unduly utilized for political rather than economic ends.

Regardless of ideological stances, it is a fact that preference for market economy and free trade has dominated economic and political thinking of recent decades and as things stand, will probably continue to do so. At the same time, as even ardent advocates of market economy would concede, it is no longer acceptable to leave economic fate of nations to the volatility of unbridled laissez-faire nor deny the wide range of economic responsibilities of governments today. The ideal solution is a new comprehensive theoretical framework capable of accommodating the essential interaction between economic and political variables in the modern state without compromising the effectiveness of economic policy tools. But until such an ideal theoretical foundation is laid, the logical option is to revisit the existing macroeconomic schools without prejudgment, and bearing in mind the extent of their logical validity, practical capabilities and limitations in different economic circumstances, use an eclectic kit of analytical and policy tools supported by apposite institutions and procedures.

\section{References}

Abbas, S. A., Blattner, L., De Broeck, M., ElGanainy, M. A., \& Hu, M. (2014). Sovereign debt composition in advanced economies: A historical perspective (Working Paper No. 14/162). International Monetary Fund. https:/www.imf.org/en/ Publications/WP/Issues/2016/12/31/SovereignDebt-Composition-in-Advanced-Economies-AHistorical-Perspective-41899

Allen, F., Goldstein, I., Jagtiani, J., \& Lang, W. W. (2016). Enhancing prudential standards in financial regulations. Journal of Financial Services Research, 49(2), 133-149. https://doi.org/10.1007/ s10693-016-0253-2

Amadeo, K. (January 21, 2020). US budget deficit by year compared to GDP, debt increase, and events. The Balance. https://www.thebalance.com/usdeficit-by-year-3306306
André, C. (2016). Household debt in OECD countries: Stylized facts and policy issues (OECD Economics Department Working Paper No. 1277). OECD Publishing. https://doi. org/10.1787/5jm3xgtkk1f2-en

Banister, J. (Dec 2004); Manufacturing employment and compensation in China. BLS. https://hdl. handle.net/1813/77468

Bank of England. (2020). Official bank rate history. https://www.bankofengland.co.uk/boeapps/ database/Bank-Rate.asp

Bianco, K. M. (2008). The subprime lending crisis: Causes and effects of the mortgage meltdown. $\mathrm{CCH}$, Wolters Kluwer Law \& Business.

Bouis, R., Rawdanowicz, Ł., Renne, J. P., Watanabe, S., \& Christensen, A. K. (2013). The effectiveness of monetary policy since the onset of the financial crisis (Working Paper No. 1081). OECD Economics Department. https://econpapers.repec.org/ RePEc:oec:ecoaaa:1081-en

Chandy, L., Brina, S. (2016, November 18). Donald Trump and the future of globalization. Brookings Institution. https://www.brookings.edu/blog/upfront/2016/11/18/donald-trump-and-the-futureof-globalization/

Chantrill, C. (2019). UK deficit since World War II [Data set]. UK Public Spending. https:// www.ukpublicspending.co.uk/spending_ chart_1947_2017UKp_17c1lo111mcn_H0t_UK_ Deficit_Since_World_War_II

ChinaPower. (2017, September 28). Is it a risk for America that China holds over $\$ 1$ trillion in U.S. debt? China Power Project. Center for Strategic and International Studies. https://chinapower. csis.org/us-debt/

Committee on the Global Financial System. (2018). Structural changes in banking after the crisis. Bank for International Settlements. https://www.bis. org/publ/cgfs60.htm

Davidson, P. (2009). The Keynes solution: The path to global economic prosperity. St. Martin's Press.

De Santis, R. A. (January 24, 2012). The euro area sovereign debt crisis: Safe haven, credit rating agencies and the spread of the fever from Greece, Ireland and Portugal (European Central Bank Working Paper No. 1419). SSRN Electronic Journal. https:// ssrn.com/abstract $=1991159$

The Economist. (June 16, 2005). In come the waves. http://www.economist.com/node/4079027

Elyassi, H. (2018). Survival of OPEC and Saudi-Iran relations-A historical overview. Contemporary 
Review of the Middle East, 5(2), 137-155. https:// doi.org/10.1177\%2F2347798918762199

European Central Bank (2021). Key ECB interest rates [Data set]. ECB. https://www.ecb.europa.eu/stats/ policy_and_exchange_rates/key_ecb_interest_ rates/html/index.en.html

Fedprimerate.com (2020). Federal funds target rate history. http://www.fedprimerate.com/ fedfundsrate/federal_funds_rate_history.htm

FRED Economic Data (2017, April 20). Consumer price index: OECD groups: all items non-food and nonenergy for the group of seven [Data set]. Economic Research, Federal Reserve Bank of St. Luis. https:// fred.stlouisfed.org/series/CPGRLE01G7A657N

FRED Economic Data (2018, March 12). Unemployment rate in the United Kingdom [Data set]. Economic Research, Federal Reserve Bank of St. Luis. https://fred.stlouisfed.org/series/ UNRTUKA

FRED Economic Data. (2018, May 24). All-transactions house price index for the United States [Data set]. Economic Research, Federal Reserve Bank of St. Luis. https://fred.stlouisfed.org/series/USSTHPI

FRED Economic Data. (2018, August 10). Consumer price index: All items for the United States [Data set]. Economic Research, Federal Reserve Bank of St. Luis. https://fred.stlouisfed. org/series/USACPIALLMINMEI

FRED Economic Data (2019, April 12). Hourly earning manufacturing in Germany [Data set]. Federal Bank of St. Luis. https://fred.stlouisfed.org/series/ LCEAMN01DEA661N

FRED Economic Data (2020, February 7). Average hourly earnings of production and non-supervisory employees [Data set]. Federal Bank of St. Luis. https://fred.stlouisfed.org/series/AHETPI

FRED Economic Data (2020, February 18). Hourly wage rate: Industry for Italy [Data set]. Federal Bank of St. Luis. https://fred.stlouisfed.org/series/ LCWRIN01ITQ661S

FRED Economic Data (2021, January 11). Total reserves excluding gold for China [Data set]. Federal Reserve Bank of St. Louis. https://fred. stlouisfed.org/series/TRESEGCNM052N

Furman, J. (2008, January 28). Recession prevention: Keynes was right. Brookings Institution. https:// www.brookings.edu/opinions/recessionprevention-keynes-was-right/

Gamble, A. (1988). The Free Economy and the Strong State: the politics of Thatcherism. Macmillan.

The Global Economy. (2020) China: Household consumption, percent of GDP [Data set].
The GlobalEconomy.com. https://www. theglobaleconomy.com/china/household_ consumption/

Gopinath, G. (2020, April 14). The Great Lockdown: Worst economic downturn since the Great Depression. IMFBlog. https://blogs.imf. org/2020/04/14/the-great-lockdown-worsteconomic-downturn-since-the-great-depression/

Gould, B. (2008, September 6). Don't bank on the bankers. The Guardian. https://www.theguardian. com/commentisfree/2008/sep/06/gordonbrown. bankofenglandgovernor

Gradziuk, A. (May 11, 2010). Problem of Undervalued Rate of Chinese Currency. The Polish Institute of International Affairs. 71(147), 273-274.

The Guardian (September 11, 2008). No return to boom and bust: What Brown said when he was chancellor. https://www.theguardian.com/ politics/2008/sep/11/gordonbrown.economy

Hufbauer, G. C., \& Goodrich, B. (January 2003). Steel policy: The good, the bad and the ugly. Peterson Institute for International Economics. https:// piie.com/publications/policy-briefs/steel-policygood-bad-and-ugly

Huwart, J-Y., \& Verdier, L. (2013). Economic Globalization, Origins and Consequences. OECD Publishing.

Ihrig, J., \& Marquez, J. (2004). An empirical analysis of inflation in OECD countries. International Finance, 7(1), 61-84. https://doi.org/10.2139/ ssrn. 415443

IMF Staff. (2000). Globalization: Threat or opportunity. International Monetary Fund. http://www.imf. org/external/np/exr/ib/2000/041200to.htm\#II

IMF (June 2020). A crisis like no other, an uncertain recovery. https://www.imf.org/en/Publications/ WEO/Issues/2020/06/24/WEOUpdateJune2020

IMF (2021). Real GDP growth [Data set]. https://www. imf.org/external/datamapper/NGDP_RPCH@ WEO/OEMDC/ADVEC/WEOWORLD

Jain-Chandra, S., Khor, N., Mano, R., Schauer, J., Wingender, P., \& Zhuang, J. (June 2018). Inequality in China - Trends, drivers and policy remedies. Inequality in China-Trends, Drivers and Policy Remedies, IMF eLibrary. https:// www.elibrary.imf.org/view/IMF001/251749781484357538/25174-9781484357538/251749781484357538_A001.xml?redirect=true

Johnson, C. (1991). The Economy under Mrs. Thatcher 1979-90. Penguin.

Justiniano, A. (February 27, 2015). What caused the last housing boom? World Economic Forum, Geneva. 
https://www.weforum.org/agenda/2015/02/whatcaused-the-last-housing-boom/

Keynes, J. M. (1936). Theory of Employment, Interest and Money. Macmillan.

Kilian, L. (2009). Oil price shocks, monetary policy and stagflation (CEPR Discussion Paper No. DP7324). SSRN Electronic Journal. https://ssrn. com/abstract $=1433920$

King, M. (2017, May 5). How the Bank of England was set free. The Financial Times. https://www.ft.com/ content/388fae86-3184-11e7-9555-23ef563ecf9a

Liu, Y. (2012). Foreign direct investment in China: Interrelationship between regional economic development and location determinants of foreign direct investment (Doctoral Dissertation, University of Western Sydney). http://handle. uws.edu.au:8081/1959.7/531221

Macintyre, D. (2014, June 16). How the miners' strike of 1984-85 changed Britain for ever. NewStatesman. https://www.newstatesman.com/ politics/2014/06/how-miners-strike-1984-85changed-britain-ever

Macrotrends (2021). Dollar Yuan Exchange Rate. 35 Year Historical Chart [Data set]. macrotrends. com. https://www.macrotrends.net/2575/usdollar-yuan-exchange-rate-historical-chart

Mann, C. L. (2017). Global economic Outlook: Better, but not good enough. Organisation for Economic Cooperation and Development. https://www. issuelab.org/resource/oecd-economic-outlookbetter-but-not-good-enough.html

Morrison, W.M., \& Labonte, M. (2013). China's holdings of US securities: Implications for US economy. Congressional Research Service Washington D.C.

Murse, T. (2020, January 17). History of the US federal budget deficit. ThoughtCo. https://www. thoughtco.com/history-of-us-federal-budgetdeficit-3321439

Napolitano, G.(2011). Thetwowaysofglobalgovernance after the financial crisis: Multilateralism versus cooperation among governments. International journal of constitutional law, 9(2), 310-339. https:// doi.org/10.1093/icon/mor038

Niskanen W. A. (1988). Reaganomics: An insider's account of the policies and the people. Oxford University Press.

OEIC. (2019). Greece External Debt: \% GDP. OIEC Data. https://www.ceicdata.com/en/indicator/ greece/external-debt--of-nominal-gdp

Office for National Statistics (2019, December 20) BOP: Trade in goods and services balance as per cent of GDP [Data set]. Office for National
Statistics. https://www.ons.gov.uk/economy/ nationalaccounts/balanceofpayments/timeseries/ $\mathrm{d} 281 / \mathrm{pnbp}$

Organisation for Economic Cooperation and Development. (June 30, 2014). International direct investment statistics [Data set]. OECD iLibrary. https://doi.org/10.1787/2307437x

Organisation for Economic Cooperation and Development. (2018). Price level indices [Data set]. OECD Data. https://data.oecd.org/price/pricelevel-indices.htm

Organisation for Economic Cooperation and Development. (2019). National accounts of OECD countries [Data set]. OECD iLibrary. https://doi. org/10.1787/22214461

Organisation for Economic Cooperation and Development (2020), General government (deficit indicator) [Data set]. OECD Data. https://doi. org/10.1787/cc9669ed-en

Pierson, P. (1994). Dismantling the welfare state? Reagan, Thatcher and the politics of retrenchment. Cambridge University press.

Pehnelt, G. (2007). Globalization and Inflation in OECD Countries (Jena Economic Research Paper No. 2007-055).SSRN Electronic Journal. https:// dx.doi.org/10.2139/ssrn.1022901

Peltier, C. (2015). China's external accounts in transition. BNP Paribas. https://economicresearch.bnpparibas.com/pdf/en-US/Chinaexternal-accounts-transition-7/23/2015,25853

Pettinger, T. (2019, July 9). UK Wage Growth. Economics Help. https://www.economicshelp. org/blog/6994/economics/uk-wage-growth/

Prevost, D., Choukroune, L., Creemers, R., \& Huchet, J. F. (2011). EU-China trade relations. Directorate-General for External Policies of the Union, Directorate B, European Parliament. https://www.europarl.europa.eu/RegData/ etudes/etudes/join/2011/433861/EXPO-INTA_ ET(2011)433861_EN.pdf

Quandl (2019, August 21). Crude Oil Prices from 1861 [Data set]. Quandl Financial, Economic and Alternative Data. https://www.quandl.com/data/ BP/CRUDE_OIL_PRICES

Rascoe, A. (Sept. 24, 2019). Trump to UN General Assembly: 'The Future Does Not Belong To Globalists'. National Public Radio (npr).

https://www.npr.org/2019/09/24/762351729/ president-trump-to-address-u-n-generalassembly? $\mathrm{t}=1613129736562$

Riddell, T. (1989). Inflationary impact of the Vietnam War. Vietnam Generation, 1(1), 4. 
Setser, B. W., Pamdey, A. (2009). China's \$1.7 trillion bet. Council on Foreign Relations. https://www. cfr.org/report/chinas-15-trillion-bet

Shiratsuka, S. (2005). The asset price bubble in Japan in the 1980s: lessons for financial and macroeconomic stability. BIS papers, 21, 42-62.

Social Security Administration (2020). Measure of central tendency for wage data [Data set]. U.S. Social Security. https:/www.ssa.gov/oact/cola/ central.html

Sprague, S. (2014). What can labor productivity tell us about the US economy. Beyond the Numbers, 3(12), 1-7.

Stark, J. (2011, September 24). Global financial crisis and the role of monetary policy. European Central Bank. https://www.ecb.europa.eu/press/key/ date/2011/html/sp110924.en.html

Statista (2020a). Gross domestic product (GDP) year-on-year growth in the United Kingdom (UK) from 1949 to 2019 [Data set]. https:// www.statista.com/statistics/281734/gdp-growthin-the-united-kingdom-uk/

Statista (2020b). Unemployment rate in the United Kingdom from 1971 to 2019 [Data set]. https://www.statista.com/statistics/279898/ unemployment-rate-in-the-united-kingdom-uk/

Statista (2020c). Euro (EUR) to Chinese Yuan Renminbi (CNY) average annual exchange rate from 2001 to 2019 [Data set]. https://www. statista.com/statistics/412827/euro-to-yuanaverage-annual-exchange-rate/

Statista (2020d). Global market size of outsourced services for 2000-2019 [Data set]. https:// www.statista.com/statistics/189788/globaloutsourcing-market-size/

US Census Bureau. (2020a). Trade in goods with China (1985-2017) [Data set].. https://www.census.gov/ foreign-trade/balance/c5700.html

US Census Bureau. (2020b). Newly privately-owned housing units completed (annual data) [Data set]. https://www.census.gov/construction/nrc/ historical_data/index.html

US Census Bureau. (2020c). U.S. trade in goods and service [Data set]. https://www.census.gov/ foreign-trade/guide/sec2.html\#bop

United States Patent and Trademark Office (02.25.2020). U.S. patenta calendar years 1790 to the present [Data set]. https://www.uspto.gov/ web/offices/ac/ido/oeip/taf/h_counts.htm

Veltmeyer, H. (2005). Development and globalization as imperialism. Canadian Journal of Development Studies/Revue canadienne d'études du développement, 26(1), 89-106. https://doi.org/10. 1080/02255189.2005.9669027

Whalen, C. J., \& Reichling, F. (2015). The fiscal multiplier and economic policy analysis in the United States. Contemporary Economic Policy, 33(4), 735-746. https://doi.org/10.1111/ coep. 12104

White, M. C. (2019, August 12). Trump's trade war could spark a recession, Goldman Sachs warns. NBC News. https://www.nbcnews.com/business/ economy/trump-s-trade-war-could-sparkrecession-warns-goldman-sachs-n1041501

World Bank. (2017). Employment in industry (as \% of total employment) $(1973$ - 2017) (modelled ILO estimates). World Bank Data. https:// data.worldbank.org/indicator/SL.IND.EMPL.ZS

World Bank. (2018a). Military expenditure (\% GDP) [Data set]. Stockholm International Peace Research Institute (SIPRI), Yearbook: Armaments, Disarmament and International Security. https:// data.worldbank.org/indicator/MS.MIL.XPND. GD.ZS?locations $=\mathrm{OE}$

World Bank. (2018b). GDP growth (annual \%) 19612016 [Data set]. World Bank national accounts data, and OECD National Accounts data files. https://data.worldbank.org/indicator/NY.GDP. MKTP.KD.ZG?page

World Bank. (2019). Domestic credit to private sector by banks [Data set]. International Monetary Fund, International Financial Statistics and data files, and World Bank and OECD GDP estimates. https://data.worldbank.org/indicator/FD.AST. PRVT.GD.ZS 


\section{Appendix 1}

Relation between Movements in Budgetary Balance and Balance of Trade in USA. (\$bn.)

\begin{tabular}{lcc}
\hline Year & B of Budget & BOT \\
\hline 1998 & 69 & -166 \\
1999 & 126 & -258 \\
2000 & 236 & -372 \\
2001 & 128 & -361 \\
2002 & -156 & -419 \\
2003 & -378 & -494 \\
2004 & -413 & -610 \\
2005 & -318 & -714 \\
2006 & -248 & -761 \\
2007 & -161 & -705 \\
\hline
\end{tabular}

Source: 2020; US Census Bureau, 2020c

Regression result shows meaningful correlation between balance of payments and balance of trade movements $(\mathrm{r}=$ $0.723927)$

\section{Appendix 2}

Correlation between Base Rate and Economic Growth and Unemployment (UK)

\begin{tabular}{lccc}
\hline Year & Base Rate* $^{*}$ & GDP growth \% & Unemployment \% \\
\hline 1998 & 6.94 & 3.6 & 6.2 \\
1999 & 5.42 & 3.4 & 6 \\
2000 & 5.88 & 3.4 & 5.4 \\
2001 & 4.96 & 3 & 5.1 \\
2002 & 4.00 & 2.3 & 5.2 \\
2003 & 3.67 & 3.3 & 5 \\
2004 & 4.38 & 2.4 & 4.8 \\
2005 & 4.50 & 3.2 & 4.8 \\
2006 & 4.88 & 2.8 & 5.4 \\
2007 & 5.50 & 2.4 & 5.3 \\
2008 & 3.96 & -0.3 & 5.7 \\
2009 & 1.00 & -4.2 & 7.6 \\
2010 & 0.5 & 1.9 & 7.9 \\
2011 & 0.5 & 1.5 & 8.1 \\
2012 & 0.5 & 1.5 & 8 \\
2013 & 0.5 & 2.1 & 7.6 \\
\hline
\end{tabular}


Correlation between Base Rate and Economic Growth and Unemployment (UK) (Continued)

\begin{tabular}{lccc}
\hline Year & Base Rate* $^{*}$ & GDP growth \% & Unemployment \% \\
\hline 2014 & 0.5 & 2.6 & 6.2 \\
2015 & 0.5 & 2.4 & 5.4 \\
2016 & 0.25 & 1.9 & 4.9 \\
2017 & 0.5 & 1.9 & 4.4 \\
2018 & 0.75 & 1.3 & 4.1 \\
2019 & 0.25 & 1.4 & 3.8 \\
\hline
\end{tabular}

Source: Bank of England 2020; Statista 2020a; Statista 2020b.

Note: ${ }^{\star A v e r a g e ~ a n n u a l ~}$

With the onset of the crisis, the government introduced a rescue plan for failing financial institutions which expanded the budget deficit. From 2010, however, budget austerity was applied, and the Bank of England assumed main responsibility for reviving the economy.

The following are result of regression of economic growth and unemployment on the BoE Base Rate:

No meaningful correlation between rate of growth of GDP and the Base Rate for data range 1998 to 2019: $(r=0.436559)$.

Weak correlation between rate of growth of GDP and the Base Rate for data range 2008 to 2019: $(r=-0.38865)$.

Weak correlation between rate of unemployment and the Base Rate for data range 1998 to 2019: $(\mathrm{r}=-0.25134)$.

Insignificant correlation between rate of unemployment and the Base Rate for data range 2008 to 2019: $(r=-0.02265)$. 